\title{
A COMPARISON OF THE TRADITIONAL AND ONLINE MEDIA AUDIENCES IN SPAIN
}

\author{
Comparación de las audiencias tradicional y online \\ de los medios en España
}

Nereida Cea-Esteruelas

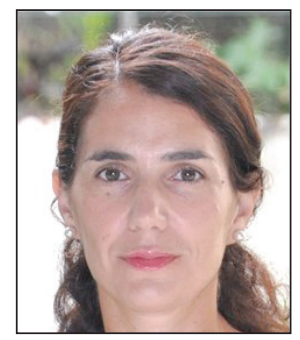

Nereida Cea-Esteruelas has a PhD in information science from the University of Navarra and master's degrees in digital journalism (University of the Basque Country) and interactive advertising (Complutense University of Madrid). She has worked as a journalist in La verdad (Grupo Vocento), La economía (Grupo Intereconomía), and El mundo (Unidad Editorial). In the area of political and institutional communication, she was responsible for communication at the Chamber of Commerce of Murcia and advisor at the Ministry of the Presidency of Murcia. Currently she teaches at the Universitat Oberta de Catalunya and contributes to the economic magazine Cinco días. http://orcid.org/0000-0002-7733-9366

Av. de los Andaluces, 46. 29688 Estepona (Málaga), España nereidacea@gmail.com

\begin{abstract}
This study is a comparative analysis of traditional media audiences and their digital extensions. The purpose of the analysis is to determine if there is a relationship between the audience of a newspaper, radio, or television and that of its digital counterparts. In order to explore if there is a relationship between online and traditional audiences, a quantitative analysis is carried out by applying the Pearson correlation coefficient to the audience information obtained from the General media survey (EGM, Estudio general de medios). The results show that a correlation does exist between online and traditional audiences in the types of media analyzed (Pearson's $r=0.682$ ).
\end{abstract}

\section{Keywords}

Cybermedia; Internet; Online media; Digital media; Audience; Newspapers; Radio; Television.

\section{Resumen}

El estudio tiene como objetivo el análisis comparativo de audiencias en medios de comunicación en su soporte tradicional y en su extensión digital. La finalidad es constatar la existencia de una relación entre la audiencia de un periódico, radio o televisión, con respecto a su medio homólogo digital. Para mostrar la relación existente entre las audiencias online y traditional se realiza un estudio cuantitativo con datos de audiencia del EGM (Estudio general de medios), aplicando el coeficiente de correlación de Pearson. Los resultados muestran que existe una correlación entre las audiencias tradicionales y online en los medios de comunicación analizados (Pearson $r=0.682$ ).

\section{Palabras clave}

Cibermedios; Internet; Medios digitales; Medios online; Audiencia; Periódicos; Radio; Televisión.

Cea-Esteruelas, Nereida (2016). "A comparison of the traditional and online media audiences in Spain". El profesional de la información, v. 25, n. 3, pp. 351-357.

http://dx.doi.org/10.3145/epi.2016.may.04

\section{Introduction}

\subsection{Objectives}

The objective of this article is to analyze the relationship between traditional media audiences and their digital extensions. This study is important because there have been changes in the experience of media audiences as shown through the migration of consumption and movement of audiences towards online markets.

From the perspective of audience studies, the Internet occupies a privileged position, because it is the driving force behind the changes in cultural industries and communication markets. The evolution of audiences, which is mainly characterized by a migration towards digital and interactive 
environments, is further evidence of a series of profound changes being experienced by the communications' sector and the media industry. In view of these circumstances, there is a need for studies that describe, from an empirical perspective, media audiences and the relationship that may or may not exist between traditional media and their digital extensions.

The following paragraphs take a theoretical approach to the main concepts in this article, and offer a review of prior studies and academic contributions addressing this subject matter. Subsequently, after presenting the methodology of the empirical study, the results are explained. Finally, suggestions are put forward for new studies which, using other methodologies, may serve to relate the results of the audience analysis to other reception variables.

\section{The audiences are mainly characterized by a migration towards digital and inte- ractive environments}

\subsection{Theoretical framework and bibliographical re- view}

Academic tradition has indeed opted, in its majority, to avoid audience measurement studies with a predominantly statistical approach. However, the changes produced with the arrival of interactive media requires researchers to approach the study of the changing paradigms in media consumption from this perspective as a preliminary step, or at least a complementary one, to the tradition of reception studies.

In fact, audience studies have become an object of renewed interest with the arrival of the Internet and interactive media (Livingstone, 2004). This change in interest is due to the need to evaluate the impact of new communication practices on consumption and its interaction with traditional media. In this regard, amongst the audience studies that have focused their analysis on the Internet in relation to other media, we highlight the work of Portilla (2003) and Larrañaga (2008), who, using a quantitative methodology, analyzed the influence of the evolution of different media on the audience.

Additional researchers have analyzed the relationship between traditional media audiences and their digital extensions (Bromley; Bowles, 1995; Dimmick; Chen; Li, 2004; Nguyen; Western, 2006; Lamas, 2010; Larrañaga, 2008; 2009; Díaz-Noci, 2010; Guallar, 2011). Stempel, Hargrove, and Bernt (2000) studied the relationship between the growth in the use of the Internet to changes in media. Dutta-Bergman (2004) established a pattern in consumption of news types across traditional and new media.

Also, researchers have investigated changes in the use of traditional media: Napoli (2011) described how new technologies exercise influence in the transformation of media audiences. Along the same lines, Webster \& Ksiazek (2012) offer a theoretical framework for understanding fragmentation, from the point-of-view of the audience. Hasebrink \&
Popp (2006), with the aim of analyzing the audience, proposed the concept of media repertoires, referring to the entirety of media that a person regularly uses; and Hasebrink \& Domeyer (2012) developed this theoretical concept.

There have also been publications of in-depth and longitudinal audience studies and analyses that focused on comparing the different types of media and the Internet in Spain (Larrañaga, 2008) specific to the press (Méndez; Lamas, 2003), radio (Del-Valle, 2003), and television (Igartua et al., 2003). Other audience studies have analyzed the phenomenon of the erosion of traditional media as a consequence of the migration of audiences towards digital media and the changes in the model of media consumption (Chyi; Silvie, 2000; Chyi; Lasorsa, 2002; Carveth, 2004; Larrañaga, 2008; Yang; Chyi,2011).

In regards to the theoretical framework, definitions are provided below of certain theoretical concepts used in this study. The terms "online" and "traditional" are used throughout this paper with reference to different areas or fields of communication. Furthermore, these terms serve to contrast the traditional media market as opposed to that of its digital extension. For some authors the online and traditional world represents two different areas of communication. For $\operatorname{Orgad}(2009$, p. 515), the separation between analogue and digital is increasingly a conceptual, analytical, and methodological.

\section{We study the interrelations between on- line and traditional from the perspective of mutual influence, rather than from the perspective of the impact of the Internet in the traditional world}

The author of this article suggests conceiving of these online and traditional spaces as a process in which meanings flow through different technologies, channels, spaces, and structures. This concept of transition better adjusts to the idea of the eruption of new media. In this way, the author suggests investigating the interrelations between online and traditional from the perspective of mutual influence, rather than from the perspective of the impact of the Internet in the traditional world. Among the reasons are an avoidance of technological determinism and extreme constructivism, which ignores the technological characteristics and the context of the process of mediated communication (Orgad, 2009, pp. 515-516).

The work of Juanatey-Boga \& Martínez-Fernández (2012) is important because it analyzed the interaction between the circulation of three newspapers (EI mundo, Marca, and Expansión) and the audience of their digital versions. These authors concluded that there was an interaction between the printed editions and the digital version of the same newspaper. They used a methodological approach based on descriptive statistics. In summary, they compared the data of the Oficina de Justificación de la Difusión (data on the circulation of the traditional medium and the online audience) through Pearson's coefficient. Their conclusions showed 
that the relationship between the online and traditional medium has the effect of "cannibalizing" the printed newspaper. This can be observed in the examples analyzed: the newspaper Expansión for the economic press, and Marca for the sports press. Starting from the conclusions of the article by Juanatey-Boga \& Martínez-Fernández (2012).

The aim of this study is to expand upon the conclusions drawn by Juanatey-Boga \& Martínez-Fernández and go deeper into the relationship between online and traditional media, extending the analysis to a group of originally printed, radiophonic, and audio-visual media. Finally, it should be noted this study hypothesizes that there is a relationship between online and traditional media audiences, that is, between traditional media audiences and their digital extension, as yet another expression -although undoubtedly a very significant one- of the transition experienced by communication markets. In this manner, all of the changes brought online by the Internet and the new media formats imply a change of communicative scenery, as it moves from traditional to digital in a context of mutual interdependence and interrelation of media consumption.

The evolution of traditional media consumption, as a consequence of the eruption of the Internet, is expressed through a migration towards interactive environments. Although this matter is analyzed throughout this article, we emphasize that this is merely an expression of more profound changes in audience behavioral patterns and media consumption.

\section{Material and methods}

\subsection{Development of the investigation}

The investigation process followed the inductive method. Hence, the investigation moved from the observation of specific realities to the formulation of more general principles. The crossing of the data, by comparing online and traditional media audiences, allowed conclusions to be drawn about the evolution of the different types of media and their corresponding digital extensions. Then, following the inductive method, conclusions were drawn from a series of specific premises. The specific premises were obtained from comparing the online and traditional media audiences that comprised the sample group. From the sum of the specific premises, certain general conclusions are made that are applicable to each of the units studied of the same type.

The inductive process had four stages: the observation of the facts and the registration of the data; the comparative study of the registered data; the inductive analysis; and the cross-checking of the results to confirm the validity of the same.

The analysis was carried out based on secondary data from the General Media Survey (hereinafter, EGM), carried out by the Association for the Investigation of the Media (AIMC) Asociación para la Investigación de los Medios de Comunicación), 2013. The sample group was limited to 20 cybermedia -online news sites- with the largest audiences. The choice of the EGM as the source of audience data, despite the existence of other equally valid measurement systems, was due to the fact that it could easily be adapted to the purpose of this study. Given that the objective of this study was to compare audiences in different media (press, magazines, radio, television, and the Internet), the most appropriate measurement system was the EGM because it offered audience data from the different types of media, applying the same methodology, in respect to the same population sample and with data covering the same time period.

Hence, despite the advantages of other measurement systems ${ }^{1}$, the EGM was chosen because it allowed for the comparison of homogeneous data in respect to the collection methodology.

Returning to the sample group, the author would like to point out that three more cybermedia were added to the study (now up to 23 total), because three of the top 20 were excluded when they did not meet the selection criteria. The three websites that were among the top 20 in the initial sample, but were ultimately excluded, were YouTube (position 1), Páginas amarillas (position 12), and Loterías y Apuestas (position 15), because they were websites that did not correspond to the type of the cybermedium with a parent medium in press, radio, or television.

Finally, it should be noted that some pure players (digital natives) do not appear in the sample, such as elconfidencial, eldiario.es, público.es, 20minutos.es, libertaddigital.com, huffingtonpost.es, vozpopuli.com, etc. These are digital media that only have an online edition, which is why they are

Chart 1. Sample group and basic information

\begin{tabular}{|c|c|c|c|}
\hline $\begin{array}{c}\text { Sample } \\
\text { unit }\end{array}$ & Medium & Traditional* & Online* \\
\hline 1 & Marca & $4,847,000$ & $2,835,000$ \\
\hline 2 & Elpaís & $4,484,000$ & $1,851,000$ \\
\hline 3 & As & $2,611,000$ & $1,372,000$ \\
\hline 4 & Antena 3 & $2,387,000$ & $1,820,000$ \\
\hline 5 & Rtve & $1,855,000$ & $1,718,000$ \\
\hline 6 & La sexta & $1,640,000$ & $1,068,000$ \\
\hline 7 & Sport & $1,347,000$ & 652,000 \\
\hline 8 & $A b c$ & $1,212,000$ & 577,000 \\
\hline 9 & Lavanguardia & $1,182,000$ & 748,000 \\
\hline 10 & El mundo deportivo & $1,122,000$ & 629,000 \\
\hline 11 & Europa Fm & $1,100,000$ & $1,930,000$ \\
\hline 12 & Elperiódico & $1,057,000$ & 633,000 \\
\hline 13 & El economista & 651,000 & 61,000 \\
\hline 14 & Expansión & 636,000 & 171,000 \\
\hline 15 & La razón & 631,000 & 268,000 \\
\hline 16 & El jueves & 615,000 & 555,000 \\
\hline 17 & Onda cero & 513,000 & $2,384,000$ \\
\hline 18 & La voz de Galicia & 503,000 & 585,000 \\
\hline 19 & Kiss Fm & 484,000 & 884,000 \\
\hline 20 & Cinco días & 360,000 & 55,000 \\
\hline \multicolumn{2}{|l|}{ Average } & $1,461,850$ & $1,039,800$ \\
\hline
\end{tabular}

Compiled using EGM - May 2013

*Traditional: newspapers, number of readers/day; radio, listeners/day; television, viewers/day.

*Online: number of users/yesterday. 
Chart 2. Correlations

\begin{tabular}{|l|l|c|c|}
\hline \multicolumn{2}{|c|}{} & Traditional & Online \\
\hline \multirow{4}{*}{ Traditional } & Pearson correlation & 1 & $0.682^{* *}$ \\
\cline { 2 - 4 } & Sig. (2-tailed) & & 0.001 \\
\cline { 2 - 4 } & $\mathrm{N}$ & 20 & 20 \\
\hline \multirow{3}{*}{ Online } & Pearson correlation & $0.682^{* *}$ & 1 \\
\cline { 2 - 4 } & Sig. (2-tailed) & 0.001 & \\
\cline { 2 - 4 } & $\mathrm{N}$ & 20 & 20 \\
\hline
\end{tabular}

** Correlation is significant at the 0.01 level (2-tailed).

not in the study. This is in spite of their deserving special attention as a news phenomenon. In fact, these digital media sites are becoming a popular news source and gaining ground on traditional media, to the point where some of them -as in the case of El confidencial, if unique visitors are considered- are situated amongst the most followed digital media, according to Comscore.

\subsection{Statistical analysis: Pearson correlation coeffi- cient}

Given that the objective of this study is to establish and, if appropriate, quantify the degree of the relationship between two groups of variables -namely, traditional and online audiences-, a statistical index was chosen that allows for the measurement of the association between two quantitative variables. The application of the Pearson correlation coefficient permits the measurement of the linear relationship between two variables. Furthermore, because it is a numeric value, it indicates the degree of the relationship that exists between these two groups of variables, and also the extent to which these two variables relate.

Before applying the Pearson coefficient, the Student's $t$ test was carried out. This test is important to validate the size and representative nature of the sample. This procedure is used to compare the means and standard deviations of the data group. If this test is correct, it serves to discard the possibility that any small difference in a sample unit may turn out to be statistically significant or, on the other hand, that a large difference may be statistically insignificant. To this end, the so-called significance level is checked. After performing a contrast of hypothesis using the Student's $t$ formula, a probability value of 0.555 is obtained, which indicates that there is a $4 \%$ probability of error. Hence, the value obtained is deemed appropriate and statistically valid in social sciences (Berganza, 2005, p. 137). The data compiled in chart 2 is obtained using the Excel software data analysis option.

Once the sample group is validated, the Pearson coefficient is applied. We should remember that the two variables to be studied are the audience of a group of traditional format media (traditional) and the corresponding digital extension or cybermedia (online). The resulting numeric value of this relationship must fluctuate between +1 and -1 . When the Pearson correlation index is +1 or near to +1 , it reflects the existence of a perfect direct linear relationship (positive) between the two variables. If, on the contrary, the result is an index of -1 , or near this value, it means that the relation- ship between the variables is linear, although in this case it is referred to as perfect inverse in light of the negative value. This value is obtained here because the low $X$ values are associated with high values of $\mathrm{Y}$. In other words, when the direct relationship is positive due to the increase or decrease of the $X$ values, the values associated with $Y$ also increase or decrease. On the other hand, a correlation of $0(r=0)$ for two variables reflects the absence of a linear relationship between the compared variables.

\section{Analysis and results}

The following statistical formula was used for the calculation of the statistical index for the Pearson correlation coefficient. The index is obtained by dividing the covariance by the product of the standard deviations of both variables. The data was previously tabulated using Excel. After applying the correlation coefficient to the two variables, the result shows that if $r=0.682$ (chart 2), we can be certain that a moderate correlation exists between the online and traditional media audiences analyzed in the sampling.

The next step was to analyze whether this relationship between the variables remained homogeneous according to the type of media (of printed, radio, or audiovisual origin) or whether, on the contrary, the correlation between the online and traditional audiences was higher or lower in any one group.

In order to do this, the 20 sample units were grouped according to the traditional parent medium. Included in the printed media group were: Marca, El país, As, Sport, Abc, La vanguardia, El mundo deportivo, El periódico, El economista, Expansión, La razón, La voz de Galicia, and Cinco días; and their respective digital extensions. On the other hand, Europa Fm, Onda cero and Kiss Fm were analyzed as radio media; and Antena3, Rtve, and La sexta as audiovisual media.

\section{In printed media it was found the highest level of correspondence, between online and traditional media audiences}

The application of the Pearson correlation coefficient to media of printed origin resulted in a value of 0.957 , which is close to 1 . Therefore, the correlation between the online and traditional audiences of printed media may be high. The same index was subsequently applied to the rest of the observation units, grouped as radio media and audiovisual media. The results show that, as with printed media, in television media the correlation of online and traditional audiences remains high (Pearson's $r=0.803$ ), and may be qualified as high positive; however, in radio media the correlation of online and traditional audiences is low (Pearson's $r=0.263$ )

Therefore, the breakdown of the analysis by type of media, namely printed, radio or audiovisual media, shows a correlation of online and traditional media that is very high in respect to the press, high in respect to audiovisual media, and low in respect to radio media. 
Chart 3. Correlations. Grouping of the Pearson coefficient results according to categories

\begin{tabular}{|c|c|c|c|c|}
\hline & & & Traditional & Online \\
\hline \multirow{6}{*}{ Press } & \multirow{3}{*}{ Traditional } & Pearson correlation & 1 & $0.957^{*}$ \\
\hline & & Sig. (2-tailed) & & 0.000 \\
\hline & & $\mathrm{N}$ & 14 & 14 \\
\hline & \multirow{3}{*}{ Online } & Pearson correlation & $0.957^{* *}$ & 1 \\
\hline & & Sig. (2-tailed) & 0.000 & \\
\hline & & $\mathrm{N}$ & 14 & 14 \\
\hline \multirow{6}{*}{ Radio } & \multirow{3}{*}{ Traditional } & Pearson correlation & 1 & 0.263 \\
\hline & & Sig. (2-tailed) & & 0.831 \\
\hline & & $\mathrm{N}$ & 3 & 3 \\
\hline & \multirow{3}{*}{ Online } & Pearson correlation & 0.263 & 1 \\
\hline & & Sig. (2-tailed) & 0.831 & \\
\hline & & $\mathrm{N}$ & 3 & 3 \\
\hline \multirow{6}{*}{ TV } & \multirow{3}{*}{ Traditional } & Pearson correlation & 1 & 0.803 \\
\hline & & Sig. (2-tailed) & & 0.406 \\
\hline & & $\mathrm{N}$ & 3 & 3 \\
\hline & \multirow{3}{*}{ Online } & Pearson correlation & 0.803 & 1 \\
\hline & & Sig. (2-tailed) & 0.406 & \\
\hline & & $\mathrm{N}$ & 3 & 3 \\
\hline
\end{tabular}

** Correlation is significant at the 0.01 level (2-tailed)

\section{Discussion and conclusions}

The main objective of this study was to establish whether or not a relationship exists between online and traditional media audiences. The hypothesis was that a relationship does exist between the size of the audience of traditional medium and that of its digital extension, within a context of the re-ordering of media consumption, characterized by a progressive migration towards digital and interactive environments.

After having formulated the hypothesis and defined the variables, the methodological procedure was established. The investigation used secondary audience data obtained from the EGM (Estudio General de Medios) survey. This source was chosen because the AIMC (Asociación para la Investigación de los Medios de Comunicación) survey offers audience information from various media (press, magazines, radio, television, and Internet), obtained by applying the same methodology, in respect to the population sample and time period.

This study followed a quantitative data analysis research technique, using the Pearson correlation coefficient statistical index. This statistical index measured the relationship between two variables and took on a numeric value, which reflects the strength of the linear relationship between two variables $(x, y)$.

The application of this index, by means of a bivariate analysis, confirmed the relationship between the observation units: there was a proportional relationship between on and traditional media audiences. Using a Pearson coefficient = 0.682 for the group of observation units, our findings indicate a moderate positive correlation between the traditional media audience and that of its digital extensions.
After dividing the 20 observation units into subcategories according to the type of media (print, radio, or audiovisual), the results of a detailed analysis showed the correspondence between the online and traditional media audiences is very high in printed media (Pearson's $r=$ 0.957), high in respect to audiovisual media (Pearson's $r=$ 0.803 ), and moderate in respect to radio media (Pearson's $r=0.263$ ). This means that, when the traditional media audience grows (press, radio, and audiovisual), the audience of its digital or online extension also grows; therefore, the proportion of the number of readers shows a very high level of agreement, this being high in the case of television viewers and moderate in the case of radio listeners, in respect to the Internet users of these same types of media.

In conclusion, the results suggest that the highest level of correspondence, between online and traditional media audiences, is to be found in printed media. On the opposite side, radio has a lower level of correspondence between online and traditional audiences. The possible reasons for these differences are as numerous as they are complex, and this article does not delve into an exploration of these possibilities. However, there may be a link between mobile device use and radio content consumption. Also, the eruption of new distributors of audio content, like Spotify, are changing the rules of both play and competition which may be influencing consumption patterns.

It is important to note that correlation between audiences does not imply causality. It goes beyond our objective to propose reasons for this fact; however, we suggest that the differentiated behavior of the audience in respect to the different media and the characteristics of the media from a content and formal perspective, as well as the affect of other random variables, may explain the different correspondence indices according to the type of media.

\section{Radio has a lower level of correspon- dence between online and traditional audiences}

Furthermore, in the future it would be interesting to extend the application of this study to research covering periodic series, in such a manner that the evolution of the strength of the relationship between the audiences could be established.

Finally, it should be pointed out that it would be advantageous to conduct qualitative cross studies, like those proposed herein, with future studies that propose ethnographic audience research, which would allow for a deeper investigation into the uses and motivations of its users from other perspectives. Similarly, the study of the factors that come into play in the mediation process would shed some light on the changes experienced by media audiences. In this way, the further investigation of different contexts would allow the audience to be studied more as an active subject than as an object. 


\section{Note}

1. El mundo and its digital extension elmundo.es does not appear among the media comprising the sample, despite the fact that, according to other audience measurement sources, it would be among the media with the highest audience. This is due to the fact that, at the express request of the company, this digital media is not audited in the EGM.

\section{References}

Berganza, Rosa (2005). “La aplicación de métodos estadísticos a la investigación de los medios de difusión". In: Berganza, Rosa; Ruiz, José (coords.). Investigar en comunicación: guía práctica de métodos y técnicas de investigación social en comunicació. Madrid: McGraw-Hill, pp. 113-148.

Bromley, Rebekah V.; Bowles, Dorothy (1995). "Impact of Internet on use of traditional news media. Newspaper". Research journal, v. 16, n 2, pp. 14-27.

Carveth, Rod (2004). "The economics of online media". In: Alexander, Alison; Owers, James; Carveth, Rod; Hollifield, C. Ann; Greco, Albert N. (eds.). Media economics. Theory and practice. New Jersey: Lawrence Erlbaum Associates, pp.265282. ISBN: 0805845801

http://citeseerx.ist.psu.edu/viewdoc/download?doi=10.1.1. 476.3955\&rep=rep1\&type $=p d f$

Chyi, Hsiang-Iris; Lasorsa, Dominic L. (2002). “An explorative study on the market relation between online and print newspapers". The journal of media economics, v. 15, n. 2, pp. 91-106.

http://dx.doi.org/10.1207/S15327736ME1502_2

Chyi, Hsiang-Iris; Sylvie, George (2000). “Online newspapers in the US: Perceptions of markets, products, revenue, and competition". International journal on media management, v. 2, n. 2, pp. 69-77.

http://dx.doi.org/10.1080/14241270009389924

Del-Valle-Brena, Almudena (2003). “Medición de audiencias de televisión en España: una perspectiva histórica". In: Igartua, Juan-José (Coord.). Audiencias y medios de comunicación. Salamanca: Universidad de Salamanca, pp. 43-55. ISBN: 9788478007257

Díaz-Noci, Javier (2010). “Medios de comunicación en internet: algunas tendencias". El profesional de la información, v. 19, n. 6, pp. 561-567.

http://recyt.fecyt.es/index.php/EPI/article/view/epi.2010.nov.01

Dimmick, John; Chen, Yan; Li, Zhan (2004). “Competition between the Internet and traditional news media: The gratification-opportunities niche dimension". Journal of media economics, v. 17, n. 1, pp. 19-33.

http://dx.doi.org/10.1207/s15327736me1701_2

Dutta-Bergman, Mohan (2004). "Complementarity in consumption of news types across traditional and new media". Journal of broadcasting and electronic media, v. 48, n. 1, pp. 41-61.

http://dx.doi.org/10.1207/s15506878jobem4801_3

Guallar, Javier (2011). “Prensa digital en 2010". Anuario ThinkEPI, v. 5, pp. 101-105.
http://recyt.fecyt.es/index.php/ThinkEPI/article/view/30477

Hasebrink, Uwe; Domeyer, Hanna (2012). “Media repertoires as patterns of behaviour and as meaningful practices: A multimethod approach to media use in converging media environments". Journal of audience \& reception studies v. 9, n. 2, pp. 757-779.

http://www.participations.org/Volume\%209/Issue $\% 20$ 2/40\%20Hasebrink\%20Domeyer.pdf

Hasebrink, Uwe; Popp, Jutta (2006). “Media repertoires as a result of selective media use. A conceptual approach to the analysis of patterns of exposure". Communications, v. 31, n. 3, pp. 369-387.

http://dx.doi.org/10.1515/COMMUN.2006.023

Igartua, Juan-José; Muñiz, Carlos; Elena, Noemí; Elena, Aránzazu (2003). "El consumo televisivo desde la perspectiva de los usos y gratificaciones". In: Igartua, Juan-José (Coord.). Audiencias y medios de comunicación. Salamanca: Universidad de Salamanca, pp. 147-160. ISBN: 978 8478007257

Juanatey-Boga, Óscar; Martínez-Fernández, Valentín-Alejandro (2012). "Difusión de la prensa diaria en España 19982008: papel vs digital". El profesional de la información, v. 21, n. 2, pp. 154-159.

http://recyt.fecyt.es/index.php/EPI/article/view/epi.2012.mar.05

Lamas, Carlos (2010). "Los medios interactivos y su publicidad: la medición de audiencias". Telos: Cuadernos de comunicación e innovación, v. 82, pp. 95-101.

https://telos.fundaciontelefonica.com/seccion=1268\&idioma=es_ ES\&id $=2010020409130001$ \&activo $=6$.do

Larrañaga, Julio (2008). “Análisis económico de la evolución de las audiencias de los medios tradicionales e impacto de Internet en su consumo". Área abierta, v. 21, pp. 1-18.

http://revistas.ucm.es/index.php/ARAB/article/view/ ARAB0808330001A

Larrañaga, Julio (2009). "La demanda de los periódicos impresos y online: un análisis económico". Ámbitos: Revista internacional de comunicación, v. 18, pp. 29-39.

http://www.redalyc.org/pdf/168/16812722002.pdf

Livingstone, Sonia (2004). "The challenge of changing audiences: or, what is the researcher to do in the age of the Internet". European journal of communication, v. 19, n. 1, pp. 75-86.

http://eprints.Ise.ac.uk/412

Méndez, Juan-Luis; Lamas, Carlos (2003). "La investigación de audiencia de medios impresos". In: Igartua, JuanJosé (Coord.). Audiencias y medios de comunicación. Salamanca: Universidad de Salamanca, pp. 67-83. ISBN: 978 8478007257

Napoli, Philip (2011). Audience evolution. New York: Columbia University Press. ISBN: 9780231150354

Nguyen, An; Western, Mark (2006). "The complementary relationship between the Internet and traditional mass media: The case of online news and information". Information research, v. 11, n. 3.

http://www.informationr.net/ir/11-3/paper259.htm/ 
Orgad, Shani (2009). "Interrelations between online and offline: Questions, issues and implications". In: Avgerou, Chrisanthi; Mansell, Robin; Quah, Danny; Silverstone, Roger (eds.). The Oxford handbok of information and communication technologies. Oxford: Oxford University Press, pp. 514537. ISBN: 9780199548798

Portilla, Idoia (2003). "La lucha por el tiempo: el efecto de Internet en la dedicación de la audiencia a otros medios". In: Arrese, Ángel (ed.). Empresa informativa y mercados de la comunicación. Pamplona: Eunsa, pp. 275-304. ISBN: 84 31320885

Stempel, Guido; Hargrove, Thomas; Bernt, Joseph (2000). "Relation of growth of use of the Internet to changes in media use from 1995 to 1999". Journalism \& mass communication quarterly, v. 77, n. 1, pp. 71-79. http://dx.doi.org/10.1177/107769900007700106

Von-Sprecher, Roberto (2009). "Estudios cualitativos en comunicación: ver lo macrosocial desde lo micro". Estudios sobre el mensaje periodístico, v. 15, pp. 525-544,

http://revistas.ucm.es/index.php/ESMP/article/view/ ESMP0909110525A

Webster, James; Ksiazek, Thomas (2012). "The dynamics of audience fragmentation: Public attention in an age of digital media". Journal of communication, v. 62, pp. 39-56. http://dx.doi.org/10.1111/j.1460-2466.2011.01616.x

Yang, Jacie-Mengchieh; Chyi, Hsiang-Iris (2011). "Competing with whom? Where? And why (not)? An empirical study of US online newspapers' competition dynamics". Journal of media business studies, v. 8, n. 4, pp. 59-74.

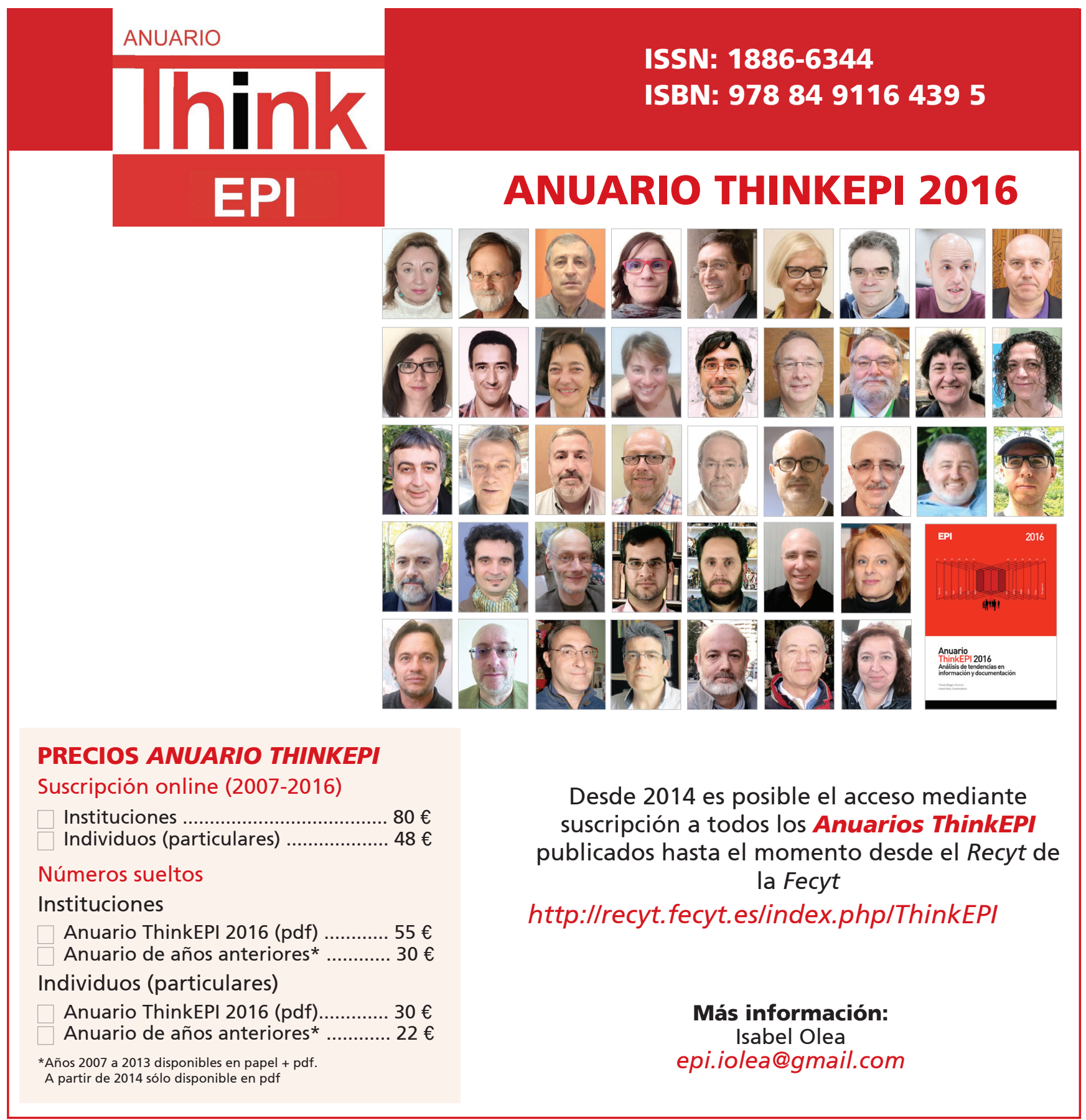

